\title{
Postojna-Planina Cave System in Slovenia, a Hotspot of Subterranean Biodiversity and a Cradle of Speleobiology
}

\author{
Maja Zagmajster ${ }^{1}{ }^{*}$, Slavko Polak ${ }^{2}$ and Cene Fišer ${ }^{1}$ \\ 1 SubBioLab, Department of Biology, Biotechnical Faculty, University of Ljubljana, Jamnikarjeva 101, \\ SI1000 Ljubljana, Slovenia; cene.fiser@bf.uni-lj.si \\ 2 Zavod Znanje Postojna, Notranjska Museum Postojna, Kolodvorska Cesta 3, SI6230 Postojna, Slovenia; \\ slavko.polak@notranjski-muzej.si \\ * Correspondence: maja.zagmajster@bf.uni-lj.si
}

check for updates

Citation: Zagmajster, M.; Polak, S.; Fišer, C. Postojna-Planina Cave System in Slovenia, a Hotspot of Subterranean Biodiversity and a Cradle of Speleobiology. Diversity 2021, 13, 271. https://doi.org/ $10.3390 / \mathrm{d} 13060271$

Academic Editors: Tanja Pipan, David C. Culver, Louis Deharveng and Michael Wink

Received: 4 May 2021

Accepted: 7 June 2021

Published: 15 June 2021

Publisher's Note: MDPI stays neutral with regard to jurisdictional claims in published maps and institutional affiliations.

Copyright: (c) 2021 by the authors. Licensee MDPI, Basel, Switzerland. This article is an open access article distributed under the terms and conditions of the Creative Commons Attribution (CC BY) license (https:// creativecommons.org/licenses/by/ $4.0 /)$.

\begin{abstract}
The Postojna-Planina Cave System (PPCS) in central Slovenia is a globally exceptional site of subterranean biodiversity, comprised of many interconnected caves with cumulative passage length exceeding $34 \mathrm{~km}$. Two rivers sink into the caves of the PPCS, called the Pivka and Rak, and join underground into Unica River, which emerges to the surface. The studies of fauna of PPCS began in the 19th century with the first scientific descriptions of specialized cave animals in the world, making it "the cradle of speleobiology". Currently, the species list of PPCS contains 116 troglobiotic animal species belonging to eight phyla, confirming its status as the richest in the world. Of these, 47 species have been scientifically described from the PPCS, and more than 10 await formal taxonomic descriptions. We expect that further sampling, detailed analyses of less studied taxa, and the use of molecular methods may reveal more species. To keep the cave animals' checklist in PPCS up-to-date, we have supplemented the printed checklist with an online interface. As the revised checklist is a necessary first step for further activities, we discuss the importance of PPCS in terms of future research and conservation.
\end{abstract}

Keywords: hotspot; speleobiology; subterranean biodiversity; troglobionts; Postojna-Planina Cave System; Slovenia

\section{Introduction}

Sampling subterranean fauna is a challenging task, considering that humans have limited access to the subterranean environment. Caves are access points to reach subterranean species that can inhabit very narrow spaces in fractured rock. Inventories of subterranean biodiversity are time consuming and require technically demanding fieldwork and broad taxonomic engagement [1]. The highest conservation priority is usually given to sites with high species richness, so completing species inventories of such hotspots should be highly prioritized [2].

The Dinaric Karst in the Western Balkans in Europe is one of the global hotspots of subterranean biodiversity [3-5]. Species richness within this region is not evenly distributed [6,7]. Many caves are consistently listed among the species richest on a global scale [8]. The species richest among them is Postojna-Planina Cave System (in Slovenian: Postojnsko planinski jamski sistem; hereafter referred to as PPCS) in Slovenia (Figure 1), outstanding not only because of its biological, but also historical, touristic, and conservation importance.

The PPCS is a complex system of many caves connected by dry or flooded channels. The inner parts of the Postojnska jama ("jama" means cave in Slovenian) at the southernmost end of the PPCS were discovered in 1818 and revealed the extraordinary richness and beauty of speleothems (Figure 2). The attractive ornamentation initiated guided tours of the cave and triggered a worldwide beginning of cave tourism. The construction of the first 
underground railway (Figure 3) and electric lighting in 1872 and 1884, respectively, promoted tourist visits to Postojnska jama. Along with tourism, scientific research developed, which laid the foundation for speleology and karstology as sciences. Biological studies of the subterranean world began with the discovery of Luka Čeč, a cave guide and assistant lamplighter, who found an unusual beetle in Postojnska jama in 1831. He gave the beetle to Count Franz Joseph Hochenwart, the curator of the Provincial Museum of Carniola in Ljubljana, who recognized the value of the find. The specimen was examined by the renowned entomologist Ferdinand Josef Schmidt, who in 1832 produced the scientific description of Leptodirus hochenwartii [9]. In this work he declared the animal to be a caveadapted beetle, which was the first scientific recognition of specialized subterranean animal in the world. News of the discovery spread and in the next years, many eminent naturalists came to study the fauna of Postojnska jama, describing cave species of other animal taxa. The snowball effect triggered by the description of L. hochenwartii is considered the starter of speleobiology and PPCS the "cradle of speleobiology" [10].

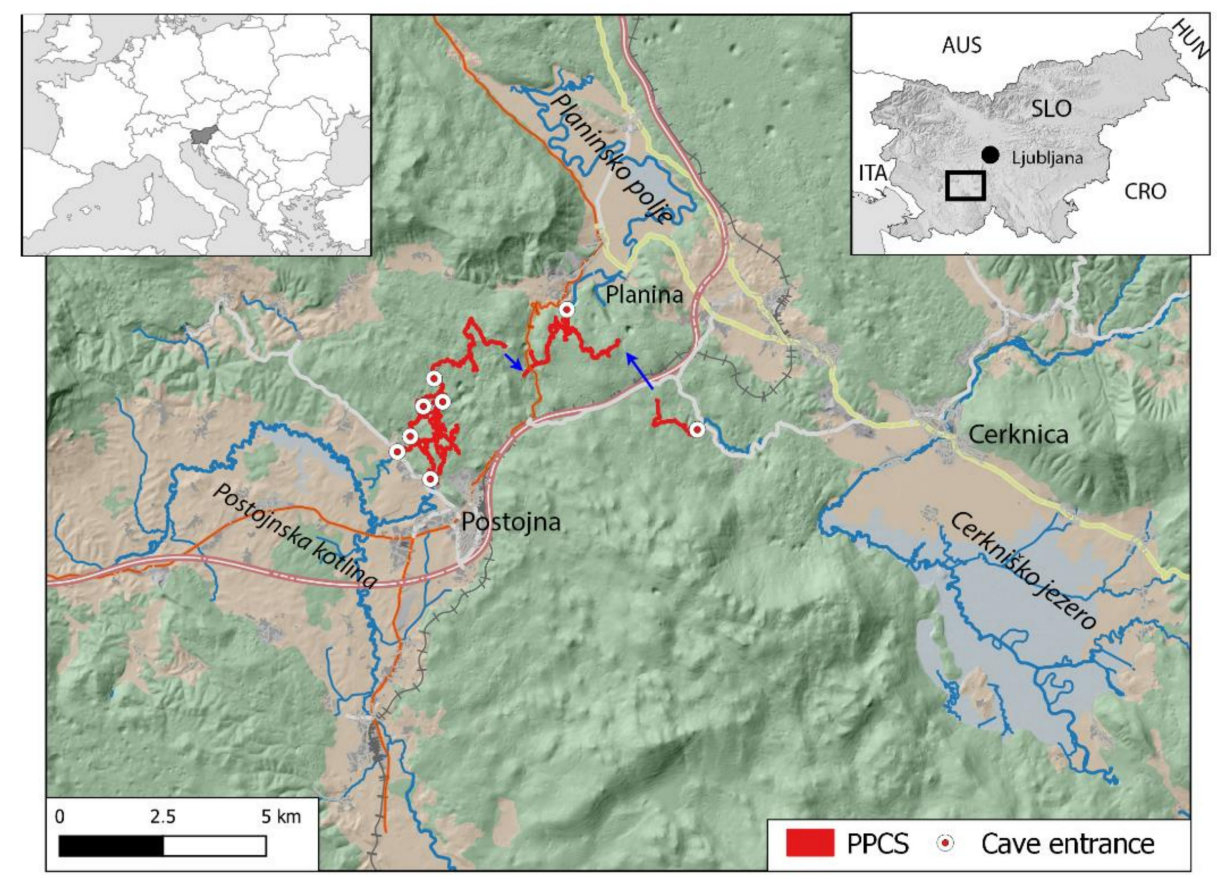

Figure 1. Location of the Postojna-Planina Cave System in central Slovenia. Top left: position of Slovenia within Europe; top right: position of PPCS within Slovenia; middle: red lines depict the planar views of all caves of the system; red dots: entrances to caves; blue arrows: parts of the system connected via subterranean rivers, but not yet passed by man.

The pace of new discoveries by numerous scientists in caves of the PPCS (see detailed review of the beginnings in [10]) produced the first checklists of the PPCS already in the 19th century. An important milestone in cataloguing was made by Benno Wolf, who collected all data on animals in caves of the world, and compiled them in Animalium Cavernarum Catalogus, issued between 1934 and 1938 [11]. However, he listed all taxa from published sources without critically evaluating their taxonomic validity, and did not distinguish the troglobiotic from non-troglobitic species. His list included 134 species for PPCS, of which about 50 could be considered troglobiotic. It was not until 30 years later, that Egon Pretner produced the next list of cave animals for PPCS, taking into account caves excluding Planinska jama in the northern part of the system [12]. Pretner listed 131 species, including about 50 troglobiotic ones. The comprehensive list of aquatic taxa from the entire PPCS, which considered the ecological status of the species, was prepared by Boris Sket in 1979 [13]. Among more than 190 species, he listed 34 aquatic troglobionts. The total number of troglobionts for PPCS, 84, was given in a comparative study of the 
richest subterranean sites in the world [8], but the actual species list was not included. We fill this gap with this paper, in which we have carefully evaluated and updated the list of troglobionts and discussed its importance within a broad socio-scientific-conservation context.

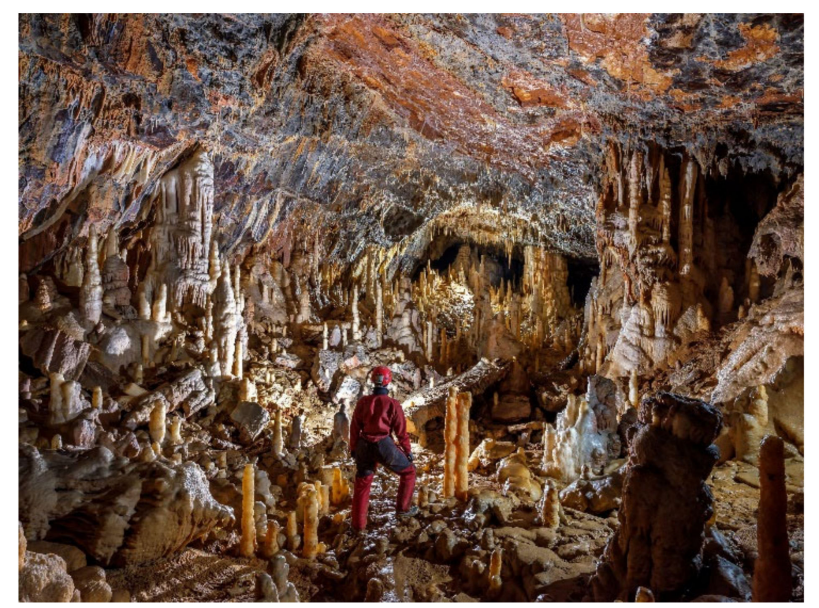

Figure 2. Postojnska jama is a tourist cave, but there are still many beautifully ornamented passages, where only cavers can enter-as the example of "Pisani rov". Photo: Peter Gedei.

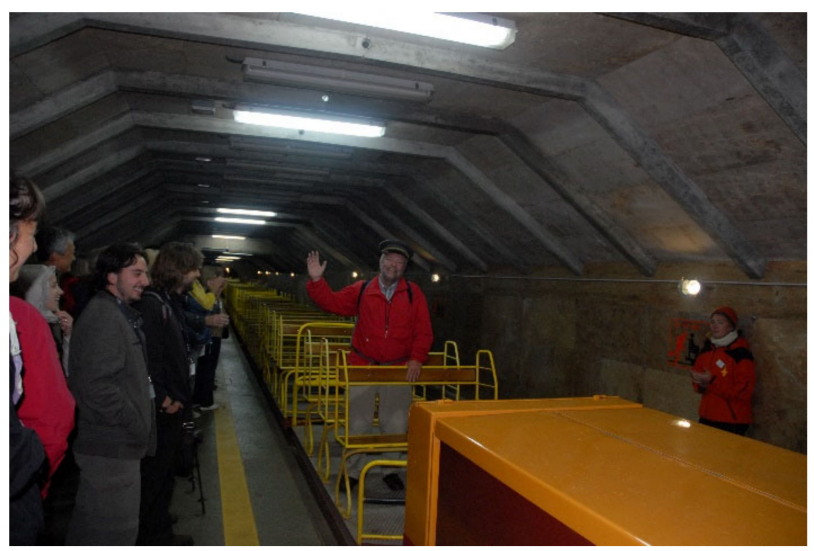

Figure 3. As a unique tourist attraction, Postojnska jama takes tourists to deep parts of the cave with the underground railway. Photo: Slavko Polak.

\section{Description of the PPCS}

The PPCS is located in central Slovenia (Figure 1). It is the main cave system in the densely forested and uninhabited karst area between the town of Postojna in Postojnska kotlina, the town of Planina on Planinsko polje, and the town of Cerknica on Cerkniško polje (Figure 1) [14]. In the area above the PPCS, there are 16 large collapsed dolinas interrupting some of these underground passages. The cave system developed in an about 800-m-thick layer of Cretaceous limestones and dolomites, between two NW-SE oriented faults, namely the northern Idrija fault and the southern Predjama fault [15]. The thickness of the bedrock above the cave ranged from 60 to $120 \mathrm{~m}$. The PPCS is typically defined as a system of six caves with large separate entrances with individual cadastre numbers in Slovenian Cadastre of Caves, namely Postojnska jama (No. 747), Otoška jama (No. 779), Pivka jama (No. 472), Črna jama (No. 471), Magdalena jama (No. 820), and Planinska jama (No. 748). Two other caves that should be considered part of the PPCS, connected via impassable flooded channels, are Lekinka (No. 1867) and Tkalca jama (No. 857) [16] (Figure 4), both of which are often excluded from biological observations of the system $[12,13]$. The entire cave system reaches depths of up to $115 \mathrm{~m}$ and includes at 
least $34 \mathrm{~km}$ of channel length ( $24 \mathrm{~km}$ of caves from Postojnska jama to Pivka jama, and approximately $10 \mathrm{~km}$ sum of the length of Lekinka, Planinska jama, and Tkalca jama).

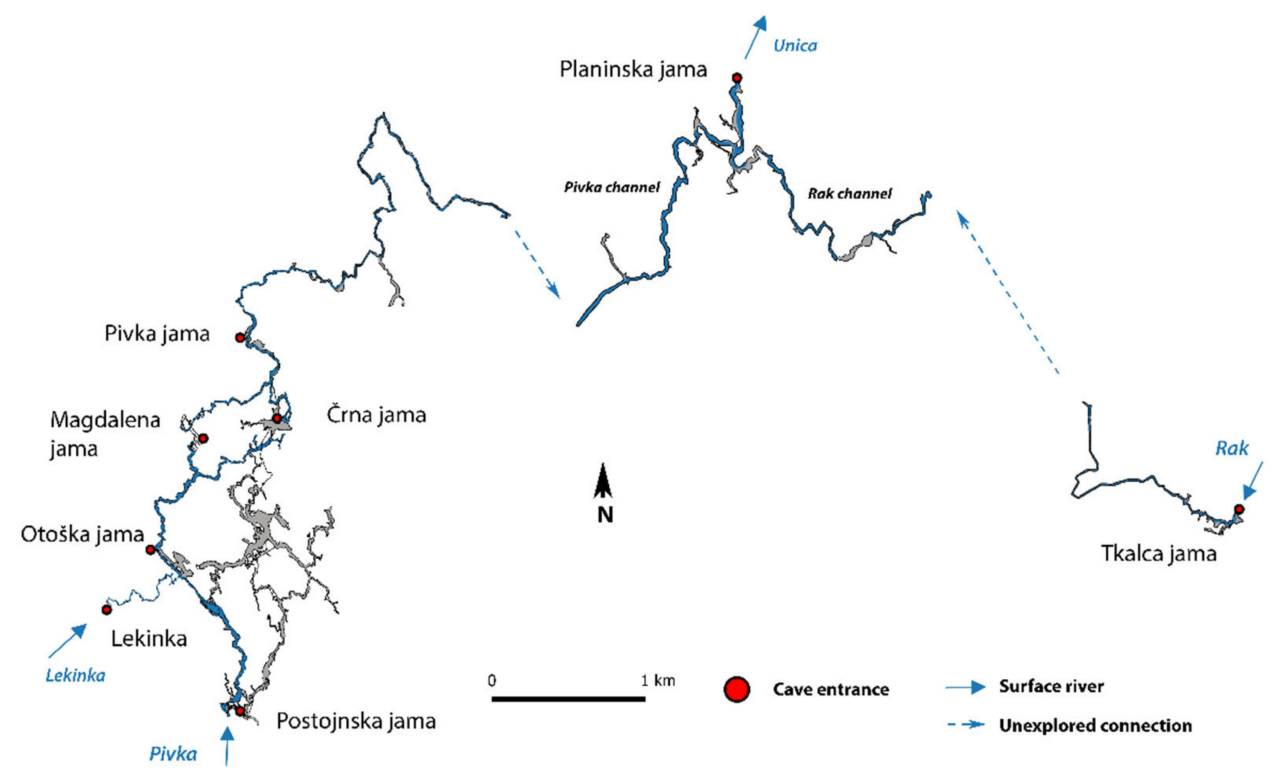

Figure 4. The plan of the Postojna-Planina Cave System, with labelled entrances to individual caves. Subterranean connections, which have not yet been explored by man, are marked with dashed blue arrow lines, while full blue arrow lines and blue names indicate surface rivers entering/leaving the system. We modified the base line outline of the caves, originally provided by the Karst Research Institute in Postojna, Slovenia.

The PPCS is located in the Black Sea drainage basin, but at least some species in the PPCS also occur in Adriatic drainage basin, indicating a complex history of drainage connectivity (Delić et al., in rev.). The PPCS contains two subterranean rivers that enter the system in the South (Pivka River) and East (Rak River). The Pivka River sinks in Postojnska jama and is directly accessible in caves up to the syphon in Pivka jama (Figure 4). It receives inflows from Lekinka and deep groundwater from the east. In 2015, parts after the siphon in Pivka jama were dived through and the length of the cave increased by about $3.5 \mathrm{~km}$, leaving a section of about $800 \mathrm{~m}$ straight line between Pivka jama and Planinska jama unexplored [17]. The Pivka River reappears in Planinska jama, the last and northernmost cave of the PPCS. In this cave, the river flows within the Pivka channel for about $2 \mathrm{~km}$, until it joins Rak River. Rak River sinks from the surface into the Tkalca jama in the east, whose channels are about $3 \mathrm{~km}$ long. Also in the Tkalca jama, one of the siphons of Rak River has stopped divers, leaving about $1 \mathrm{~km}$ of straight line distance to Planinska jama unexplored [18] (Figure 4). After the syphon, Rak River reappears in Planinska jama and flows for about $2 \mathrm{~km}$ through the Rak channel, and joins Pivka River. The new river, called Unica, is formed about $500 \mathrm{~m}$ away from the cave entrance, where it springs to Planinsko polje (Figures 1 and 4). The channels of the system along the Pivka River are vertically on two levels. The upper ones are older and dry, with many beautiful formations and speleothems (Figure 2), while the younger and lower ones called "Rov podzemne Pivke" (the channels of the subterranean Pivka River), were formed after the deepening of the riverbed.

Temperatures within the PPCS vary depending on the location of cave entrances and the distance from rivers sinks into the system. The temperature in the inner, isolated parts of Postojnska jama is about $8.5^{\circ} \mathrm{C}$, while in the parts closer to the entrances it varies mainly between 3 and $13{ }^{\circ} \mathrm{C}$ [19]. The temperature of Pivka River varies daily and seasonally, with the amplitude of fluctuations decreasing with distance from its sink [20]. Oxygen concentration in Pivka River varies similarly to surface conditions near the sink 
to Postojnska jama, while with distance from the sink the water becomes aerated and saturated with oxygen [20].

There are two main sources of organic material for subterranean communities. One is via the sinking rivers, which transport substantial amounts of particulate organic matter and, in the near-surface areas, also abundant plant and animal material that can become food sources. The transport capacity is strongly influenced by precipitation and is enhanced during high water levels [19]. The second source of organic matter is epikarst water, which drips from the ceiling and brings mainly diluted organic matter [21,22]. Another food source, albeit spatially limited, is bat guano and the remains of terrestrial accidentals coming into the PPCS. In general, the amount of organic matter in Pivka River decreases in the direction from Postojnska jama to Planinska jama [21].

\section{Compiling the Data}

We compiled the data of all troglobionts or troglobiotic populations found in PPCS (sensu Sket [23]). The latter are populations of surface species that form morphologically and ecologically distinct specialized cave populations in PPCS [24]. Non-troglobiotic species found in PPCS and dubious records were omitted from the checklist. The main source of information was published sources as well as material kept in Zoological collection of Department of Biology, Biotechnical Faculty, University of Ljubljana and Notranjska Museum Postojna. The information was collected in SubBioDB, the database on biodiversity of subterranean habitats managed in the SubBioLab at the University of Ljubljana. The data were revised and supplemented with unpublished records, either from reports or from personal communication with taxonomic authorities.

The list contains the species or the lowest taxonomic rank that could be identified. If the subspecies level was determined, we list it. We did not distinguish the level of subgenera. In some cases, taxonomic authorities specifically indicated that some individuals belonged to new species awaiting formal description. These records were added to the checklist as "Genus sp. n.".

We marked whether the PPCS presents a type locality for the taxon. Whenever data were available, we added information about the specific cave of the PPCS where the taxon was recorded.

We used the most current taxonomic nomenclature available for specific taxonomic groups. To list only valid species names, we consulted taxonomists or online databases maintained by specialists, namely World Register of Marine Species [25], Millibase [26], A World Catalogue of Centipedes (Chilopoda) [27], Pseudoscorpiones of the World [28], World Spider Catalogue [29], and Checklist of the Collembola [30]. To keep track of species names listed in previous checklists, we have retained the original species name in the list.

Because checklists may be outdated at the time they are published, we developed an online checklist of PPCS species (www.subbio.net/PPCS-checklist (accessed on 8 June 2021) that is fed from the SubBioDB database.

\section{The Checklist of Taxa in PPCS}

The checklist contains 116 species, of which 71 are aquatic and 45 terrestrial. They belong to eight phyla: 85 species of arthropods ( 45 crustaceans, 18 hexapods, 13 arachnids, and 9 myriapods), 12 molluscs, 11 annelids, 4 turbellarians, 1 sponge, 1 cnidarian, 1 vertebrate, and 1 protist (Table 1). Three species were found as parasitic on cave shrimp, the protist, and both thamnocephalids (Table 1). Nearly half, 47 species, have been scientifically described from PPCS (Table 1). In addition, two species remain to be identified at species level, while 12 are awaiting taxonomic description. Some of the most notable species are presented in Figure 5. 


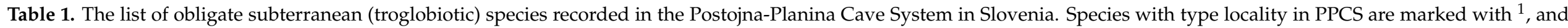

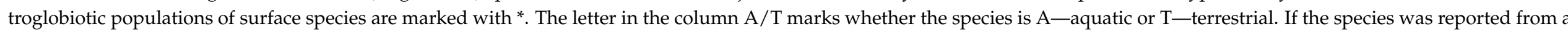

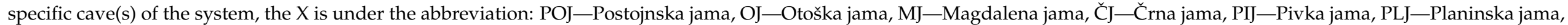
TKJ-Tkalca jama.

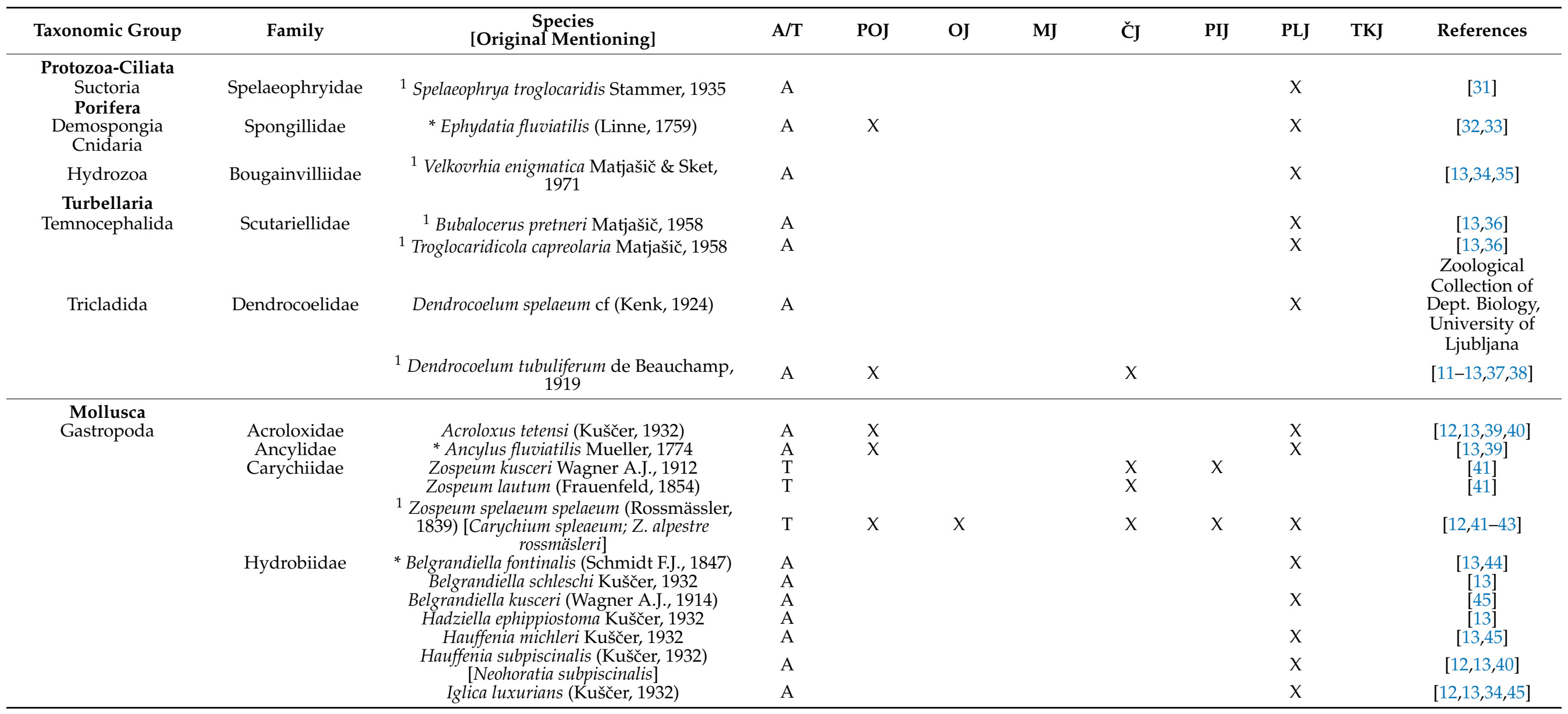


Table 1. Cont.

\begin{tabular}{|c|c|c|c|c|c|c|c|c|c|c|c|}
\hline Taxonomic Group & Family & $\begin{array}{c}\text { Species } \\
\text { [Original Mentioning] }\end{array}$ & $\mathrm{A} / \mathrm{T}$ & POJ & OJ & MJ & ČJ & PIJ & PLJ & TKJ & References \\
\hline Annelida & & & & \multirow{10}{*}{$x$} & & & & \multirow[b]{2}{*}{$x$} & & & \\
\hline Hirudinea & Erpobdellidae & $\begin{array}{c}\text { * Dina krasensis (Sket, 1968) [Trocheta } \\
\text { bykowskii krasense] }\end{array}$ & A & & & & & & $x$ & & {$[13,46]$} \\
\hline \multirow[t]{8}{*}{ Oligochaeta } & Lumbriculidae & Trichodrilus ptujensis Hrabe, 1963 & A & & & & & \multirow{8}{*}{$x$} & & & [13] \\
\hline & \multirow{7}{*}{ Tubificidae } & Trichodrilus strandi Hrabe, 1936 & A & & & & & & $X$ & & {$[13,47]$} \\
\hline & & ${ }^{1}$ Epirodrilus slovenicus Karaman Sp., 1976 & A & & & & & & $X$ & & {$[13,48,49]$} \\
\hline & & ${ }^{1}$ Potamothrix postojnae Karaman Sp., 1974 & A & & & & & & $x$ & & {$[49,50]$} \\
\hline & & $\begin{array}{l}{ }^{1} \text { Rhyacodrilus caudosetosus Karaman Sp., } \\
1983\end{array}$ & A & & & & & & $x$ & & {$[49,51]$} \\
\hline & & ${ }^{1}$ Rhyacodrilus maculatus Karaman Sp., 1983 & A & & & & & & $x$ & & {$[49,51]$} \\
\hline & & ${ }^{1}$ Rhyacodrilus sketi Karaman Sp., 1974 & $\mathrm{~A}$ & & & & & & $x$ & & {$[49-51]$} \\
\hline & & Sketodrilus flabellisetosus (Hrabe, 1966) & A & & & & & & $x$ & & {$[48,49]$} \\
\hline \multirow{4}{*}{$\begin{array}{l}\text { Arthropod } \\
\text { Acarina }\end{array}$} & rachnida & & & & & & & & & & \\
\hline & Eremaeidae & Oppia cavatica nomen nudum & $\mathrm{T}$ & & & & & & $X$ & & [52] \\
\hline & Eremaeidae & Oppia malograjskiella nomen nudum & $\mathrm{T}$ & & & & & & $X$ & & [52] \\
\hline & Labidostommidae & $\begin{array}{l}\text { 1,* Labidostomma lyra Willmann, } 1932 \\
\text { [Nicoletiella denticulata] }\end{array}$ & $\mathrm{T}$ & $x$ & & & & & & & {$[11-13,53]$} \\
\hline \multirow{2}{*}{ Araneae } & & ${ }^{1}$ Stalita taenaria Schioedte, 1847 & $\mathrm{~T}$ & $x$ & $x$ & $x$ & $x$ & & $x$ & & {$[11,12,42,54-60]$} \\
\hline & Linyphiidae & $\begin{array}{c}{ }^{1} \text { Troglohyphantes excavatus Fage, } 1919 \\
\text { [Troglohyphantes anellii] }\end{array}$ & $\mathrm{T}$ & $x$ & & & & & & & [60-62] \\
\hline Palpigrada & Eukoeneniidae & $\begin{array}{c}\text { Eukoenenia austriaca austriaca (Hansen, } \\
1926 \text { ) }\end{array}$ & $\mathrm{T}$ & $x$ & & & & & & & {$[12,63-66]$} \\
\hline \multirow{6}{*}{ Pseudoscorpiones } & Chthoniidae & Chthonius spelaeophilus Hadži, 1930 & $\mathrm{~T}$ & $X$ & & & & & & & [62] \\
\hline & & ${ }^{1}$ Chthonius cavernarum Ellingsen, 1909 & $\mathrm{~T}$ & $X$ & & & & & & & {$[11,12,67,68]$} \\
\hline & & $\begin{array}{c}\text { Troglochthonius doratodactylus Helversen, } \\
1968\end{array}$ & $\mathrm{~T}$ & $x$ & & & & & & & {$[62]$} \\
\hline & Neobisiidae & ${ }^{1}$ Neobisium pusillum Beier, 1939 & $\mathrm{~T}$ & & & & $x$ & & & & {$[12,13,69]$} \\
\hline & & ${ }^{1}$ Neobisium spelaeum spelaeum (Schioedte, & $\mathrm{T}$ & $X$ & $x$ & & & & & & {$[12,13,42,57,68]$} \\
\hline & & Roncus stussineri (Simon, 1881) & $\mathrm{T}$ & & & & & & & & [12] \\
\hline \multirow{4}{*}{$\begin{array}{l}\text { Arthropo } \\
\text { Chilopoda }\end{array}$} & Tyriapoda & & & & & & & & & & \\
\hline & Lithobiidae & Lithobius sp.n. & $\mathrm{T}$ & & & & & & & & {$[42]$} \\
\hline & & ${ }^{1}$ Lithobius stygius Latzel, 1880 & $\mathrm{~T}$ & $x$ & $x$ & & & & $x$ & & {$[12,42,70,71]$} \\
\hline & & $\begin{array}{c}{ }^{1} \text { Lithobius zveri (Matić \& Stentzer, 1977) } \\
\text { [Monotarsobius zveri] }\end{array}$ & $\mathrm{T}$ & & & & & & $x$ & & {$[72]$} \\
\hline
\end{tabular}


Table 1. Cont.

\begin{tabular}{|c|c|c|c|c|c|c|c|c|c|c|c|}
\hline Taxonomic Group & Family & $\begin{array}{c}\text { Species } \\
\text { [Original Mentioning] }\end{array}$ & $\mathrm{A} / \mathrm{T}$ & POJ & OJ & MJ & ČJ & PIJ & PLJ & TKJ & References \\
\hline Diplopoda & Attemsiidae & $\begin{array}{l}{ }^{1} \text { Attemsia stygia (Latzel, 1884) [Attemsia } \\
\text { stygium] }\end{array}$ & $\mathrm{T}$ & $x$ & $x$ & & & $x$ & & & {$[11-13,73-76]$} \\
\hline \multirow{5}{*}{ Symphyla } & Haasiidae & $\begin{array}{l}{ }^{1} \text { Haasia troglodyta (Latzel, 1884) } \\
\text { [Acherosoma troolodutes. Haasia troolodutes] }\end{array}$ & $\mathrm{T}$ & $x$ & & & & & & & {$[12,73,74]$} \\
\hline & Iulidae & Typhloiulus illirycus (Verhoeff, 1929) & $\mathrm{T}$ & $x$ & $x$ & & & & & & {$[11,62,76]$} \\
\hline & Polydesmidae & 1,* Brachydesmus subterraneus Heller, 1857 & $\mathrm{~T}$ & $x$ & & & $x$ & $x$ & & & {$[11,12,77]$} \\
\hline & Scolopendrellidae & $\begin{array}{l}1 \text { Scolopendreilopsis pretneri } \\
\text { Juberthie-Iupeau, } 1963\end{array}$ & $\mathrm{~T}$ & $x$ & & & & & & & {$[62,78]$} \\
\hline & Scutigerellidae & ${ }^{1}$ Scutigerella hauserae Scheller, 1990 & $\mathrm{~T}$ & $x$ & & & & & & & {$[62,79]$} \\
\hline Arthropoda- & Chydoridae & * Chydorus sphaericus (O.F.Mueller, 1776) & $\mathrm{A}$ & & & & & & & & {$[80,81]$} \\
\hline $\begin{array}{c}\text { Crustacea } \\
\text { Cladocera } \\
\text { Copepoda -Calanoida }\end{array}$ & Diaptomidae & $\begin{array}{l}\text { Troglodiaptomus sketi Petkovski, } 1978 \\
\text { [Troglodiaptomus sketi postojnae] }\end{array}$ & A & $x$ & & & & & $x$ & & {$[82]$} \\
\hline \multirow[t]{5}{*}{$\begin{array}{l}\text { Copeopoda- } \\
\text { Cyclopoida }\end{array}$} & Cyclopidae & Acanthocyclops kieferi (Chappuis, 1925) & A & $x$ & & & & & $x$ & & {$[82,83]$} \\
\hline & & $\begin{array}{c}\text { Acanthocyclops venustus venustus (Norman } \\
\text { \& Scott, 1906) } \\
\text { [Acanthocyclops venustus stammeri] }\end{array}$ & A & $x$ & & & & & $x$ & & {$[82,84]$} \\
\hline & & $\begin{array}{l}\text { Diacyclops languidoides (Lilljeborg, 1901) } \\
\text { [Diacuclops lanouidoides goticus] }\end{array}$ & A & $x$ & & & & & & & {$[12,13,82,83]$} \\
\hline & & Diacyclops slovenicus Petkovski, 1954 & A & $x$ & & & & & $x$ & & {$[82,84]$} \\
\hline & & $\begin{array}{c}{ }^{1} \text { Metacyclops postojnae Brancelj, } 1987 \\
\text { Speocyclops infernus (Kiefer, 1930) }\end{array}$ & $\begin{array}{l}\text { A } \\
\text { A }\end{array}$ & $\begin{array}{l}X \\
X\end{array}$ & & & $x$ & $x$ & $x$ & & $\begin{array}{c}{[82,84]} \\
{[13,82-84]}\end{array}$ \\
\hline \multirow{10}{*}{$\begin{array}{l}\text { Copepoda- } \\
\text { Harpacticoida }\end{array}$} & Ameiridae & Nitocrella n.sp. & $\mathrm{A}$ & $x$ & & & & & & & {$[83]$} \\
\hline & Canthocamptidae & Bryocamptus balcanicus (Kiefer, 1933) & $\mathrm{A}$ & $x$ & & & $x$ & $\underset{x}{x}$ & $x$ & & {$[83,87]$} \\
\hline & & $\begin{array}{c}\text { Bryocamptus n.sp. } \\
\text { Bryocamptus pyrenaicus (Chappuis, 1923) }\end{array}$ & $\begin{array}{l}\mathrm{A} \\
\mathrm{A}\end{array}$ & $x$ & & & & $\begin{array}{l}x \\
x\end{array}$ & $x$ & & {$[83,84,87]$} \\
\hline & & Bryocamptus typhlops (Mrazek, 1893) & $\mathrm{A}$ & $\hat{X}$ & & & & $\hat{x}$ & $\hat{x}$ & & {$[83,87]$} \\
\hline & & $\begin{array}{c}\text { Bryocamptus zschokkei caucasicus Borutzky, } \\
1960\end{array}$ & A & $x$ & & & & $x$ & $x$ & & {$[13,87]$} \\
\hline & & ${ }^{1}$ Elaphoidella cvetkae Petkovski, 1983 & $\mathrm{~A}$ & $x$ & & & $x$ & $x$ & $x$ & & {$[83,84,87,88]$} \\
\hline & & Elaphoidella elaphoides (Chappuis, 1924) & A & & & & & $x$ & $X$ & & [87] \\
\hline & & ${ }^{1}$ Elaphoidella franci Petkovski, 1983 & $\mathrm{~A}$ & & & & & & $x$ & & {$[84,87,88]$} \\
\hline & & ${ }^{1}$ Elaphoidella jeanneli (Chappuis, 1928) & $\mathrm{A}$ & $x$ & & & $x$ & & $x$ & & {$[12,13,84,87,89]$} \\
\hline & & Elaphoidella stammeri Chappuis, 1936 & A & $x$ & & & & & $X$ & & {$[84,87]$} \\
\hline
\end{tabular}


Table 1. Cont.

\begin{tabular}{|c|c|c|c|c|c|c|c|c|c|c|c|}
\hline Taxonomic Group & Family & $\begin{array}{c}\text { Species } \\
\text { [Original Mentioning] }\end{array}$ & $\mathrm{A} / \mathrm{T}$ & POJ & OJ & MJ & ČJ & PIJ & PLJ & TKJ & References \\
\hline \multirow{9}{*}{$\begin{array}{l}\text { Ostracoda - } \\
\text { Podocopida }\end{array}$} & \multirow{7}{*}{ Parastenocarididae } & Maraenobiotus cf. brucei (Richard, 1898) & A & & & & & $X$ & & & [83] \\
\hline & & Moraria n.sp. & $\mathrm{A}$ & & & & $x$ & & & & [83] \\
\hline & & $\begin{array}{l}\text { Morariopsis scotenophila (Kiefer, 1930) } \\
\text { Pilocamptus pilosus (Douwe, 1910) }\end{array}$ & A & $X$ & & & $x$ & & & & {$[83,84,87]$} \\
\hline & & $\begin{array}{c}\text { [Echinocamptus georgevitchi E. pilosus, E. } \\
\text { unicus] }\end{array}$ & A & $x$ & & & $x$ & $x$ & $x$ & & {$[12,13,84,87]$} \\
\hline & & Stygepactophanes sp.n. & A & & & & $x$ & & & & [83] \\
\hline & & $\begin{array}{l}\text { Horstkurtcaris nolli alpina (Kiefer, 1960) } \\
\text { [Parastenocaris nolli] }\end{array}$ & A & & & & $x$ & $x$ & & & {$[83]$} \\
\hline & & Parastenocaris sp.n. 2 & A & $x$ & & & $x$ & $x$ & & & [83] \\
\hline & \multirow[t]{2}{*}{ Candonidae } & $\begin{array}{l}{ }^{1} \text { Typhlocypris trigonella (Klie, 1931) } \\
\text { [Candona trigonella] }\end{array}$ & A & $x$ & & & & & & & {$[11-13,90,91]$} \\
\hline & & Typhlocypris schmeili nomen nudum & A & & & & $x$ & & & & {$[11-13,92]$} \\
\hline Decapoda & Atyidae & $\begin{array}{l}{ }^{1} \text { Troglocaris planinensis Birstein, } 1948 \\
\text { [Troglocaris anophthalmus] }\end{array}$ & $\mathrm{A}$ & $x$ & & & $x$ & $X$ & $X$ & $X$ & {$[12,18,34,93-95]$} \\
\hline \multirow[t]{7}{*}{ Amphipoda } & Crangonyctidae & $\begin{array}{c}\text { * Synurella ambulans Mueller, } 1846 \\
\text { [Synurella jugoslavica] }\end{array}$ & A & & & & & & $X$ & & {$[13,34]$} \\
\hline & \multirow[t]{5}{*}{ Niphargidae } & $\begin{array}{c}\text { Niphargus dobati Sket } 1999 \text { [Niphargus } \\
\text { aquilex] }\end{array}$ & A & & & & & & $x$ & & {$[96,97]$} \\
\hline & & Niphargus orcinus Joseph, 1869 & A & & & & & & & & {$[13,97]$} \\
\hline & & ${ }^{1}$ Niphargus spoeckeri Schellenberg, 1933 & A & & & & $x$ & $x$ & $X$ & & {$[12,13,34,62,97]$} \\
\hline & & ${ }^{1}$ Niphargus stygius (Schioedte, 1847) & A & $X$ & & & $\mathrm{X}$ & & $X$ & & {$[12,13,34,57,97]$} \\
\hline & & $\begin{array}{c}\text { Niphargus sp. stygius-complex (Schioedte, } \\
\text { 1847) }\end{array}$ & A & $x$ & & & $\mathrm{X}$ & & $x$ & & {$[12,34,57,97]$} \\
\hline & \multirow{4}{*}{ Asellidae } & ${ }^{1}$ Niphargus wolfi Schellenberg, 1933 & A & $x$ & & & & & $x$ & & {$[12,13,34,97]$} \\
\hline \multirow[t]{6}{*}{ Isopoda } & & * Asellus aquaticus aquaticus (Linne, 1761) & A & $x$ & & & $x$ & $x$ & $x$ & & {$[11-13,99-103]$} \\
\hline & & $\begin{array}{c}\text { 1,* Asellus aquaticus cavernicolus Racovitza, } \\
1925\end{array}$ & A & $x$ & & & $x$ & $x$ & $x$ & & $\begin{array}{c}{[11-13,101,102,} \\
104,105]\end{array}$ \\
\hline & & Proasellus istrianus (Stammer, 1932) & A & & & & & $x$ & & & {$[12,13]$} \\
\hline & Sphaeromatidae & $\begin{array}{l}\text { Monolistra racovitzai racovitzai Strouhal, } \\
1928\end{array}$ & A & $x$ & & & & & $X$ & & {$[106,107]$} \\
\hline & \multirow[t]{2}{*}{ Trichoniscidae } & $\begin{array}{l}\text { Androniscus stygius (Nemec, 1897) } \\
\text { [Andronicus cavernarum tschammeri] }\end{array}$ & $\mathrm{T}$ & $x$ & & $X$ & $x$ & & $X$ & & [12,108-111] \\
\hline & & ${ }^{1}$ Titanethes albus (Koch C., 1841) & $\mathrm{T}$ & $X$ & $\mathrm{X}$ & $X$ & $X$ & $x$ & $x$ & & $\begin{array}{l}{[12,13,42,108,} \\
110]\end{array}$ \\
\hline
\end{tabular}


Table 1. Cont.

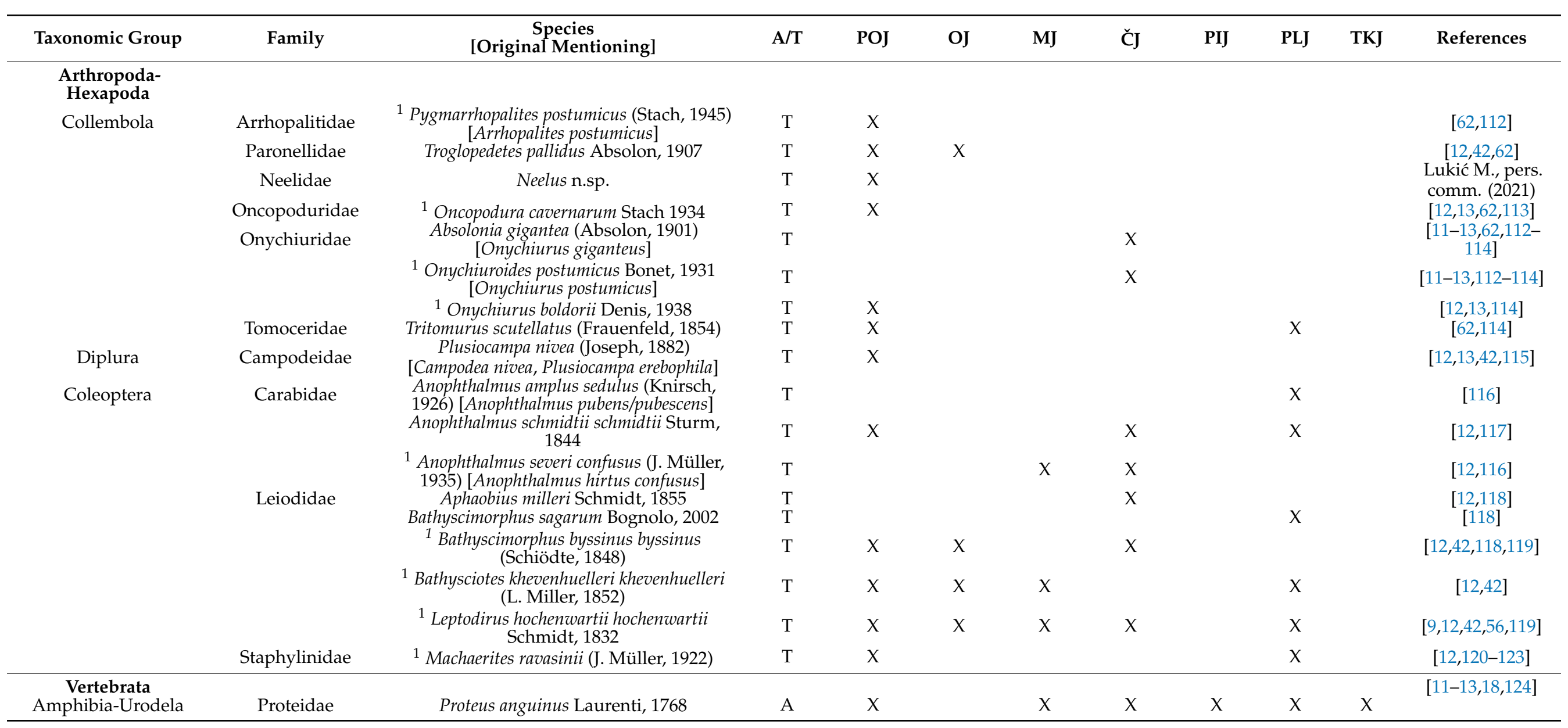



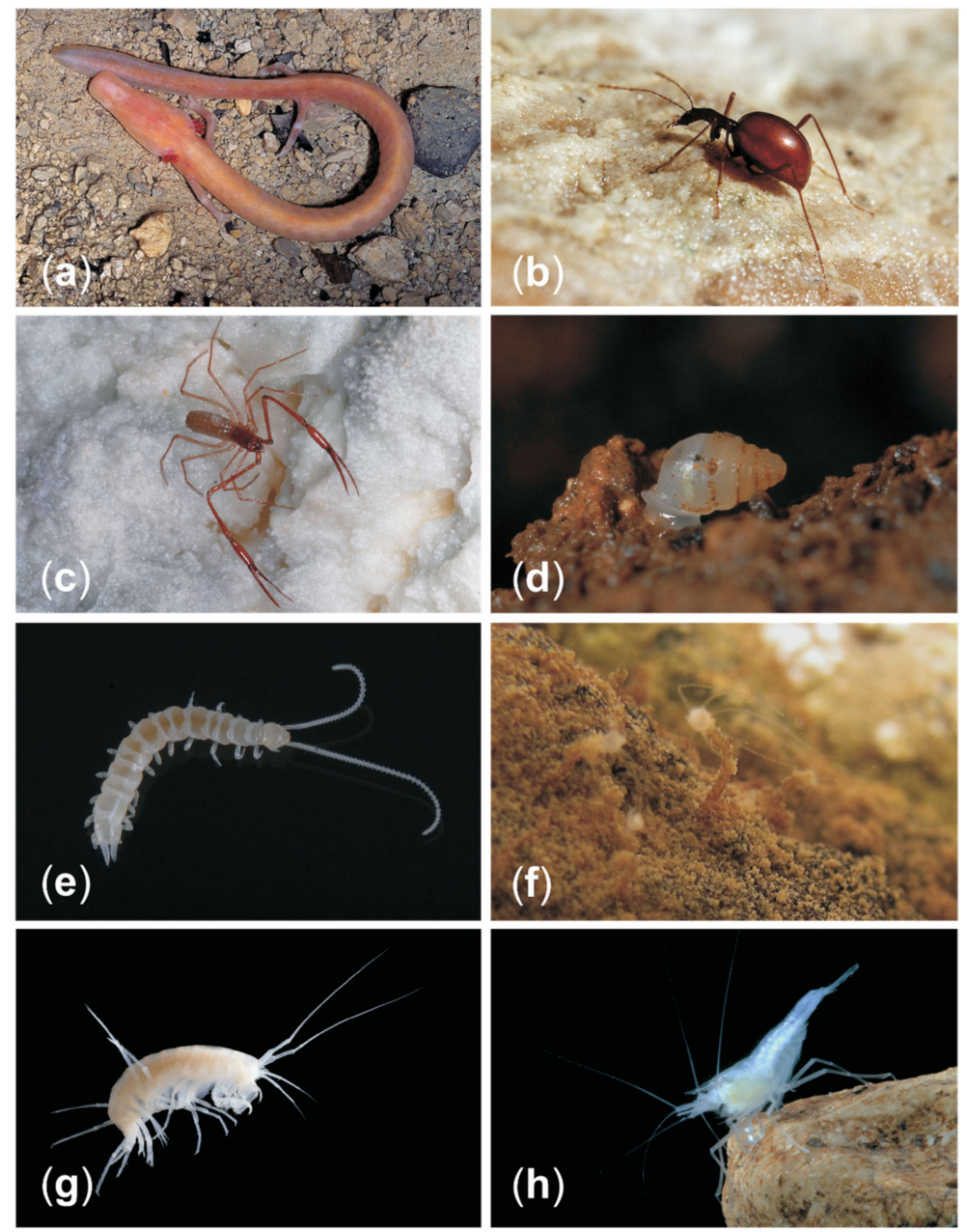

Figure 5. The famous eight: (a) proteus or the olm Proteus anguinus Laurenti, 1768; (b) slenderneck beetle Leptodirus hochenwartii hochenwartii Schmidt, 1832; (c) giant cave pseudoscorpion Neobisium spelaeum spelaeum (Schiødte, 1848); (d) Postojna cave herald snail Zospeum spelaeum spelaeum (Rossmaessler, 1839); (e) symphylan Scutigerella hauserae Scheller, 1990; (f) cave hydrozoan Velkovrhia enigmatica Matjašič \& Sket, 1971; (g) giant cave amphipod Niphargus orcinus Joseph, 1869; (h) Planina cave shrimp Troglocaris planinensis Birstein, 1948. Photo credits: (a-e)—Slavko Polak, (f)—Rodrigo Lopes Ferreira, (g)-Teo Delić, (h)—Rollin Verlinde.

Not all species were reported from all caves of the PPCS. The highest number was reported from Planinska jama (66 species) and Postojnska jama (64 species). From Črna jama, Pivka jama, Otoška jama Magdalena jama, and Tkalca jama, 35, 26, 11, 7, and 2 species were reported, respectively.

\section{Importance of Updated Checklist}

\subsection{General Comments}

The revised checklist revealed the presence of at least 116 troglobiotic species in PPCS, increasing the number by nearly 40 species since the last publication [8]. Not all species were reported from all caves of the PPCS. Due to the connectivity between the different parts of the system, the current differences in the number of species mainly reflect the differences in sampling, but also their positions in relation to the river sinks and surface influences. Although PPCS has the longest history of biological exploration, and the highest troglobiotic species richness in the world, new species are still expected. This is no surprise considering that PPCS is located in the heart of a region that has been consistently recognized as a global hotspot of subterranean biodiversity, where sampling is 
still not complete [125]. This supports the view that further studies in the system should be encouraged as they may reveal additional species for a variety of reasons: sampling of new microhabitats or more thorough sampling of less studied cave channels, use of new sampling techniques, study of currently less studied taxa [126], identification changes due to continued taxonomic activity, or introduction of molecular methods to identify cryptic species and their co-occurrence [127-129].

\subsection{PPCS as a Model System for Key Biological Questions}

PPCS retains its appeal for biological research, with organisms that have the potential to answer key questions in speleobiology [130]. One research direction could address cave colonization in the context of adaptation and speciation processes from surface ancestor to subterranean descendant [131]. In the PPCS, there are at least four species with extant surface ancestral populations, which provide an exceptional model system for studying these ecological and evolutionary processes during the transition from surface to subterranean environments [131-133].

The next potential of PPCS is to study the dynamics of community structure and interspecific interactions $[97,134]$, including distances to the entrances and/or the surface. Since the main parts of PPCS are organized along the Pivka River, this gives the opportunity to observe gradual changes in surface influences downstream. An open question is how surface and subterranean species exchange and interact along this gradient, and whether the aquatic community follows this gradient. Although it has been shown that the dynamics of the relationship between surface and subterranean taxa changes from the sink of Pivka River to the deeper parts of the cave [20], their interactions are still poorly understood. Sket [20] suggested that the degree of eutrophication affects the interactions between subterranean species and accidentals and that eutrophication may favor the competitive strength of surface invaders, a hypothesis indirectly supported in other studies $[135,136]$.

The third attractive direction is ecosystem-level oriented research on nutrient cycling, energy budget, and its top-down effects on interspecific interactions and community structure. Early studies suggest a complex pattern of organic input, likely due to the multiple windows through which PPCS communicates with the surface [21,22]. Such additional inputs in the system can affect the gradual changes of organic matter downstream. Even though more complicated, these inputs may present replicas of starting points of organic matter input and possibilities for repeated studies of changes downstream from the sources, which present an attractive venue for research.

\subsection{Challenges in Cave Management and Conservation}

PPCS is the system with one of the longest tourist uses in the world. Management of the PPCS must balance protection of high species richness with potential tourism pressure and other surface threats. Sustainable management is a serious challenge in show caves with such high visitor numbers as the PPCS, where Postojnska jama alone receives up to 500,000 visitors per year. Direct consequences are microclimatic changes, and also the introduction of artificial light, which promotes the growth of the so-called "lampenflora" as well as airborne bacteria of anthropogenic origin [137] with unknown effects on biotas. The negative impact of tourist use on the spatial arrangement of animals has been demonstrated, as they move to more remote dark/less disturbed passages [12,42].

A greater and less controlled threat to the PPCS comes from the surface, through agriculture and overuse of fertilizers and pesticides, and pollution from industry [138]. The Pivka River transports pollutants deep into the cave system, which is especially critical during high flow that tends to homogenize chemical and bacterial parameters throughout the river system [139]. Their impact on troglobiotic fauna is not studied and monitored, not even for the most charismatic species, the olm (Proteus anguinus).

In order to detect any changes in the PPCS, regular monitoring of abiotic parameters and its inhabitants should be carried out. Chemical and physical parameters of percolating water and allogenic enrichment have been monitored for decades by experts from the 
Institute for Karst Research in Postojna [140]. Permanent monitoring of cave air temperature, humidity, wind flow, and $\mathrm{CO}_{2}$ to determine human impact on the natural cave environment started in 2007. So far, only terrestrial fauna in the tourist part of Postojnska jama has been monitored since 2009. Monitoring should be extended to the entire PPCS and include aquatic fauna as well. This is especially important, considering that both L. hochenwartii and the olm are listed in the European Habitat's directive as species of special conservation concern, whose habitat must be protected and whose populations must be adequately monitored [141]. New methods, such as the use of DNA barcoding system for species identification [142], or protocols for metabarcoding [143] and e-DNA technologies [144,145], offer new opportunities for monitoring.

\subsection{PPCS Outreach and Public Awareness}

Public opinion can strengthen the long-term protection of a cave or, more generally, of subterranean habitats and their biotas. For the vast majority, tourist caves such as Postojnska jama are the only unique opportunity to personally experience the underground world. Such visits, associated with emotion, are an exceptional, albeit somewhat controversial, opportunity to engage visitors and inform them about the fragility and importance of subterranean habitats and their inhabitants, as well as about conservation issues. By restricting tourist use to a limited part of the PPCS, the rest of the system can be safeguarded from such visits, while benefitting from the personal experience gained by the visitors. This is an important prerequisite to affect their attitude toward conservation and positive view on the protection of the whole PPCS and subterranean biodiversity in general.

The fact that the PPCS is a global hotspot of subterranean biodiversity is an important opportunity to promote and present the uniqueness of subterranean environments. Steps in this direction have been made by establishing a vivarium near the entrance of Postojnska jama, an internal aquarium with olms inside the cave and two permanent exhibitions: the interactive exhibition Expo at Postojnska jama and a special speleobiological exhibition Karst Museum at Notranjska Museum Postojna.

Author Contributions: Conceptualization, M.Z., S.P. and C.F.; Data curation, M.Z., S.P. and C.F.; Formal analysis, M.Z., S.P. and C.F.; Methodology, M.Z., S.P. and C.F.; Visualization, M.Z. and S.P.; Writing-original draft, M.Z., S.P. and C.F.; Writing—review \& editing, M.Z., S.P. and C.F. All authors contributed equally to the conception of the paper, data gathering and writing. All authors have read and agreed to the published version of the manuscript.

Funding: The first and last authors were funded by Slovenian Research Agency through core funding Programme P1-0184, and by the project LIFE NarcIS - Nature Conservation Information System (LIFE19 GIE/SI/000161, co-financed by EU LIFE Programme).

Institutional Review Board Statement: Not applicable.

Informed Consent Statement: Not applicable.

Data Availability Statement: All the retrieved data occur in Table 1, and on www.subbio.net/PPCSchecklist (accessed on 8 June 2021).

Acknowledgments: We thank the editors for inviting us to contribute to this Special Issue. We thank Marko Lukić (Croatian Biospeleological Society) who allowed the use of some unpublished data on cave Collembola. Teo Delić, Rodrigo Lopes Ferreira, Rollin Verlinde and Peter Gedei contributed the photographs. We are very grateful to Uroš Stepišnik (University of Ljubljana) and Matej Blatnik (Karst Research Institute at Research Centre of the Slovenian Academy of Sciences and Arts), for providing the digital maps of caves of PPCS. We thank the members of SubBioLab who contribute the data in SubBioDB via their ongoing studies. We are grateful to former SubBioLab members Simona Prevorčnik and Boris Sket, for their involvement in the early stages of list compilation.

Conflicts of Interest: The authors declare no conflict of interest. 


\section{References}

1. Ficetola, G.F.; Canedoli, C.; Stoch, F. The Racovitzan impediment and the hidden biodiversity of unexplored environments. Conserv. Biol. 2019, 33, 214-216. [CrossRef]

2. Pipan, T.; Deharveng, L.; Culver, D.C. Hotspots of subterranean biodiversity. Diversity 2020, 12, 209. [CrossRef]

3. Zagmajster, M.; Eme, D.; Fišer, C.; Galassi, D.; Marmonier, P.; Stoch, F.; Cornu, J.-F.; Malard, F. Geographic variation in range size and beta diversity of groundwater crustaceans: Insights from habitats with low thermal seasonality. Glob. Ecol. Biogeogr. 2014, 23, 1135-1145. [CrossRef]

4. Eme, D.; Zagmajster, M.; Delić, T.; Fišer, C.; Flot, J.F.; Konecny-Dupre, L.; Palsson, S.; Stoch, F.; Zakšek, V.; Douady, C.J.; et al. Do cryptic species matter in macroecology? Sequencing European groundwater crustaceans yields smaller ranges but does not challenge biodiversity determinants. Ecography 2017, 41, 1-13. [CrossRef]

5. Culver, D.C.; Deharveng, L.; Bedos, A.; Lewis, J.J.; Madden, M.; Reddell, J.R.; Sket, B.; Trontelj, P.; White, D. The mid-latitude biodiversity ridge in terrestrial cave fauna. Ecography 2006, 29, 120-128. [CrossRef]

6. Bregović, P.; Fišer, C.; Zagmajster, M. Contribution of rare and common species to subterranean species richness patterns. Ecol. Evol. 2019, 9, 11606-11618. [CrossRef]

7. Zagmajster, M.; Culver, D.C.; Sket, B. Species richness patterns of obligate subterranean beetles (Insecta: Coleoptera) in a global biodiversity hotspot-Effect of scale and sampling intensity. Divers. Distrib. 2008, 14, 95-105. [CrossRef]

8. Culver, D.C.; Sket, B. Hotspots of subterranean biodiversity in caves and wells. J. Cave Karst Stud. 2000, 62, 11-17.

9. Schmidt, F. Beitrag zu Krain's fauna. Leptodirus hochenwartii. Illyrisches Blatt 1832, 3, 9-10.

10. Polak, S. Importance of discovery of the first cave beetle Leptodirus hochenwartii Schmidt, 1832. Endins 2005, 28, 71-80.

11. Wolf, B. Animalium Cavernarum Catalogus; Verlag für Naturwissenschafren: Berlin, Germany, 1934.

12. Pretner, E. Živalstvo Postojnske jame. In 150 Let Postojnske Jame 1818-1968; Zavod Postojnske Jame: Postojna, Slovenia, 1968; pp. 59-78.

13. Sket, B. Jamska favna Notranjskega trikotnika (Cerknica-Postojna-Planina), njena ogroženost in naravovarstveni pomen. Varst. Narave 1979, 13, 45-59.

14. Gospodarič, R. The quaternary caves developement between the Pivška kotlina (Pivka basin) and Planinsko polje (polje of Planina). Acta Carsologica 1964, 7, 5-139.

15. Šebela, S. Tectonic Structure of Postojnska Jama Cave System; Založba ZRC: Ljubljana, Slovenia, 1998.

16. Perko, G. Die Adelsberger Grotte in Wort und Bild; Internationales Museum für Höhlenkunde: Postojna, Slovenia, 1910.

17. Cvjetović, S. Potapljače so Med Premagovanjem Četrtega Sifona Spremljale Kolonije Človeških Ribic. Novice, 14 July 2015. Available online: https:/ / siol.net/novice/slovenija/potapljace-so-med-premagovanjem-cetrtega-sifona-spremljale-kolonijecloveskih-ribic-199376(accessed on 31 March 2021).

18. Ilić, U. Tkalca Jama, Potop, 27.7.2013. Available online: https://www.jd-rakek.com/index.php/novice/akcije/101-tkalca-jamapotop-27-7-2013 (accessed on 31 March 2021).

19. Pipan, T.; Petrič, M.; Šebela, S.; Culver, D.C. Analyzing climate change and surface-subsurface interactions using the Postojna Planina Cave System (Slovenia) as a model system. Reg. Environ. Chang. 2019, 19, 379-389. [CrossRef]

20. Sket, B. Predhodno poročilo o ekoloških raziskavah v sistemu kraške Ljubljanice. Biološki Vestn. 1970, $18,79-87$.

21. Simon, K.S.; Pipan, T.; Culver, D.C. A conceptual model of the flow and distribution of organic carbon in caves. J. Cave Karst Stud. 2007, 69, 1-6.

22. Simon, K.S.; Pipan, T.; Ohno, T.; Culver, D.C. Spatial and temporal patterns in abundance and character of dissolved organic matter in two karst aquifers. Fundam. Appl. Limnol. 2010, 177, 81-92. [CrossRef]

23. Sket, B. Can we agree on an ecological classification of subterranean animals? J. Nat. Hist. 2008, 42, 1549-1563. [CrossRef]

24. Konec, M.; Prevorčnik, S.; Sarbu, S.M.; Verovnik, R.; Trontelj, P. Parallels between two geographically and ecologically disparate cave invasions by the same species, Asellus aquaticus (Isopoda, Crustacea). J. Evol. Biol. 2015, 28, 864-875. [CrossRef]

25. WoRMS Editorial Board. World Register of Marine Species. 2021. Available online: http://www.marinespecies.org (accessed on 19 March 2021).

26. Sierwald, P.; Spelda, J. MilliBase. Available online: http://www.millibase.org (accessed on 19 February 2021).

27. Bonato, L.; Chagas, A.J.; Edgecombe, G.D.; Lewis, J.G.E.; Minelli, A.; Pereira, L.A.; Shelley, R.M.; Stoev, P.; Zapparoli, M. ChiloBase 2.0-A World Catalogue of Centipedes (Chilopoda). Available online: https://chilobase.biologia.unipd.it/ (accessed on $1 \mathrm{March}$ 2021).

28. Harvey, M.S. Pseudoscorpions of the World, Version 2.0. Available online: http://www.museum.wa.gov.au/catalogues/ pseudoscorpions (accessed on 1 March 2021).

29. World Spider Catalog. 2021. Available online: https:/ /wsc.nmbe.ch/ (accessed on 19 March 2021).

30. Janssen, F. Checklist of the Collembola. Available online: https:/ /www.collembola.org/ (accessed on 19 March 2021).

31. Matjašič, J. Opazovanja na jamskem suktoriju Spelaeophrya troglocaridis Stammer. Biološki Vestn. 1956, 5, 71-73.

32. Velikonja, M. Taksonomija in Sestava Favne Sladkovodnih Spužev (Porifera: Spongillidae) v Jugoslaviji s Posebnim Ozirom na Jamske in Ohridske Taksone); Inštitut za Biologijo in VZOZD za Biologijo: Ljubljana, Slovenia, 1990.

33. Sket, B.; Velikonja, M. Troglobitic freshwater sponges (Porifera, Spongillidae) found in Yugoslavia. Stygologia 1986, 2, 254-266.

34. Matjašič, J.; Sket, B. Jamski hidroid s slovenskega krasa. Biološki Vestn. 1971, 19, 139-145. 
35. Velikonja, M. Contribution to the knowledge of the biology of the yugoslav endemic cave hydroid Velkovrhia enigmatica Matjašič \& Sket, 1971. In Proceedings of the 9th Congreso Internacional de Espeleologia, Barcelona, Spain, 9-15 August 1986; pp. 123-125.

36. Matjašič, J. Vorläufige Mitteilungen über europäische Temnocephalen. Biološki Vestn. 1958, 7, 60-65.

37. De Beauchamp, P. Diagnoses preliminaires de Triclades obscuricoles. Bull. Soc. Zool. Fr. 1919, 44, $243-251$.

38. Kenk, R. Sladkovodni trikladi iz jam severozahodnega dela Dinarskega krasa. Prirodosl. Razpr. 1936, 3, 1-29.

39. Bole, J. Rodova Ancylus O. F. Muell in Acroloxus Beck (Gastropoda, Basommatophora) v podzemeljskih vodah Jugoslavije. Razprave-Dissertationes 1965, 8, 155-175.

40. Bole, J. Recentni podzemeljski polži in razvoj nekaterih porečij na dinarskem krasu. Razprave-Dissertationes 1985, $24,315-328$.

41. Bole, J. Rod Zospeum Bourguignat 1856 (Gastropoda, Ellobiidae) v Jugoslaviji. Razprave-Dissertationes 1974, 17, $249-291$.

42. Ramšak, L. Tourist Impact on Terrestiral Fauna Postojna and Otok Cave. Graduation Thesis, University of Ljubljana, Ljubljana, Slovenia, 2007.

43. Rossmässler, A.E. Iconographie der Land- und Süßwasser-Mollusken, Mit Vorzügliecher Berücksichtingung der Europäischen Noch Nicht Abgebildeten Arten; Arnoldische Buchhandlung: Dresden/Leipzig, Germany, 1839.

44. Bole, J.; Velkovrh, F. Mollusca from continental subterranean aquatic habitats. In Stygofauna Mundi; A Faunistic, Distributional and Ecological Synthesis of the World Fauna inhabiting Subterranean Waters (including the Marine Interstitial); Bachuys: Leiden, Germany, 1986; pp. 177-207.

45. Kuščer, L. Höhlen- und Quellenschnecken aus dem Flussgebiet Ljubljanica. Arch. Molluskenkd. 1932, 64, 48-62.

46. Sket, B. K poznavanju favne pijavk (Hirudinea) v Jugoslaviji. Razprave-Dissertationes 1968, 11, $129-197$.

47. Karaman, S. Trichodrilus strandi (Oligochaeta, Lumbriculidae), a new element in the fauna of Yugoslavia. Biološki Vestn. 1987, 35, 27-30.

48. Karaman, S. The second contribution to the knowledge of the freshwater Oligochaeta of Slovenia. Biološki Vestn. 1976, 24, 201-207.

49. Giani, N.; Sambugar, B.; Martínez-Ansemil, E.; Martin, P.; Schmelz, R.M. The groundwater oligochaetes (Annelida, Clitellata) of Slovenia. Subterr. Biol. 2011, 9, 85-102. [CrossRef]

50. Karaman, S. Beitrag zur Kenntnis der Süsswasseroligochaeten Sloveniens. Biološki Vestn. 1974, 22, $223-228$.

51. Karaman, S. Third contribution to the knowledge of the freshwater Oligochaeta of Slovenia. Biološki Vestn. 1983, 31, 29-36.

52. Tarman, K. Prispevek k poznavanju oribatidne favne Slovenije II. Biološki Vestn. 1958, 6, 80-91.

53. Willman, C. Acari aus sudostalpinen Hohlen. Mitteilungen uber Hohlen- und Karstforsch. Zeitschrift Hauptverbandes Dtsch. Hohlenforscher 1932, 4, 158-161.

54. Caporiacco, L. Aracnidi cavernicoli e lucifugi di Postumia. Grotte d'Italia 1937, 2, 1-8.

55. Nikolić, F. Pauci iz nekih pećina Slovenije. In Proceedings of the Treći Jugoslavenski Speleološki Kongres, Sarajevo, Yugoslavia, 21-27 June 1962; Speleološki Savez Jugoslavije: Sarajevo, Yugoslavia, 1963; pp. 157-167.

56. Pretner, E. Zgodovinski pregled koleopteroloških raziskovanj v jamah Slovenije. Acta Carsologica 1974, 6, 307-316.

57. Schioedte, C.J. Undersögesler over den underjordiske Fauna i Hulerne i Krain og Istrien. Overs. over det K. danske Vidensk. Selsk. Forh. og dets Medl. Arbeier 1847, 6, 75-81.

58. Kratochvil, J. Liste générale des araignées cavernicoles en Yougoslavie. Prirodosl. Razpr. 1934, 2, 165-226.

59. Kratochvil, J. Cavernicole Dysderae. Prirodoved. Pr. Ust. Češkoslovenske Akad. ved v Brne 1970, 4, 3-68.

60. Brignoli, P.M. Contributo alla conoscenza dei ragni cavernicoli della Jugoslavia (Araneae). Fragm. Entomol. 1971, 7, 103-119.

61. Deeleman-Reinhold, C.L. Revision of the cave-dwelling and related spiders of the genus Troglohyphantes Joseph (Linyphiidae), with special reference to the Yugoslav species. Razprave-Dissertationes 1978, 23, 1-221.

62. Polak, S. Biološki Monitoring Postojnskega Jamskega Sistema in Predjamskega Jamskega Sistema—Končno Poročilo (Final Project Report); Notranjski muzej Postojna: Postojna, Slovenia, 2014.

63. Conde, B. Acquisitions recentes chez les palpigrades. Mémoires Biospéologie 1985, 13, 33-35.

64. Conde, B.; Neuherz, H. Palpigrades de la grotte de Raudner, pres de Stiwoll (Kat. Nr. 2783/04) dans le paleozoique de Graz, Styrie, Autriche. Rev. Suisse Zool. 1977, 84, 799-806. [CrossRef]

65. Conde, B. Palpigrades (Arachnida) d'Europe, des Antilles, du Paraguay et de Thailande. Rev. Suisse Zool. 1984, 91, 369-391. [CrossRef]

66. Zagmajster, M.; Kováč, L'. Distribution of palpigrades (Arachnida, Palpigradi) in Slovenia with a new record of Eukoenenia austriaca (Hansen, 1926). Nat. Slov. 2006, 8, 23-31.

67. Hadži, J. Contribution à la connaissance des Pseudoscorpiones cavernicoles. Glas. Acad. Serbe. 1930, 140, 1-36.

68. Ćurčić, B. Catalogus faunae Jugoslaviae III/4. Arachnoidea, Pseudoscorpiones; ZRC SAZU: Ljubljana, Slovenia, 1974.

69. Beier, M. Die Höhlenpseudoscorpione der Balkanhalbinsel. Eine auf dem Material der "Biospeologica balcanica" basierende Synopsis. Stud. Gebiet. allgem. Karstforsch.wiss. Höhlenk. Eiszeitforsch. Nachbargebiet. Biol. Ser. 1939, 1, 1-83.

70. Latzel, R. Die Myriopoden der Österreichisch-Ungarischen Monarchie. Erste Hälfte: Die Chilopoden; Alfred Hölder: Vienna, Austria, 1880.

71. Matić, Z.; Darabantu, C. Contributions a la connaissance des Chilopodes de Yougoslavie. Razprave-Dissertationes 1968, 9, 199-227.

72. Matić, Z.; Stentzer, I. Beitrag zur Kenntnis der Hundertfüssler (Chilopoda) aus Slowenien. Biološki Vestn. 1977, $25,55-62$.

73. Latzel, R. Die Myriapoden der Österreichisch-Ungarischen Monarchie. Zweite Hälfe: Die Symphylen, Pauropoden und Diplopoden, Nebst Bemerkungen über Exotische und Fossile; Alfred Holder: Vienna, Austria, 1884.

74. Strasser, K. Catalogus faunae Jugoslaviae III/4. Diplopoda; ZRC SAZU: Ljubljana, Slovenia, 1971. 
75. Mršić, N. Attemsiidae (Diplopoda) of Yugoslavia. Razprave-Dissertationes 1987, 27, 101-168.

76. Strasser, K. Die Diplopoden Sloweniens. Acta Carsologica 1966, 4, 159-220.

77. Heller, K. Beiträge zur österreichischen Grotten -Fauna. Sitzungsberichte der Akad. der Wissenschaften Math. Klasse 1858, 26, 313-326.

78. Juberthie-Jupeau, L. Description d'une espece nouvelle de Symphyle recolte dans la grotte de Postojna (Yugoslavie). Ann. Speleol. 1963, 18, 299-304.

79. Scheller, U. The Pauropoda and Symphyla of the Geneva Museum IX. Symphyla from middle end south Europe, Turkey and Morocco (Myriapoda, Symphyla). Rev. Suisse Zool. 1990, 97, 411-425. [CrossRef]

80. Dumont, H.J.; Negrea, S. A conspectus of the Cladocera of the subterranean waters of the world. Hydrobiologia 1996, 325, 1-30. [CrossRef]

81. Brancelj, A. Alona hercegovinae n. sp. (Cladocera: Chydoridae), a blind cave-inhabiting Cladoceran from Hercegovina (Yugoslavia). Hydrobiologia 1990, 199, 7-16. [CrossRef]

82. Brancelj, A. Cyclopoida and Calanoida (Crustacea, Copepoda) from the Postojna-Planina cave system (Slovenia). Biološki Vestn 1987, 35, 1-16.

83. Pipan, T.; Anton, B. Distribution patterns of copepods (crustacea: Copepoda) in percolation water. Zool. Stud. 2004, 43, 206-210.

84. Brancelj, A. Male of Moraria radovnae Brancelj, 1988 (Copepoda: Crustacea), and notes on endemic and rare copepod species from Slovenia and neighbouring countries. Hydrobiologia 2001, 453, 513-524. [CrossRef]

85. Brancelj, A. Microdistribution and high diversity of Copepoda (Crustacea) in a small cave in central Slovenia. Hydrobiologia 2002, 477, 59-72. [CrossRef]

86. Kiefer, F. Kurze Diagnosen neuer Süsswasser-Copepoden. Zool. Anz. 1931, 94, 219-224.

87. Brancelj, A. Rare and lesser known Harpacticoids (Copepoda Harpacticoida) from the Postojna-Planina cave system (Slovenia). Biološki Vestn. 1986, 34, 13-36.

88. Petkovski, T.K. Neue höhlenbewonende Harpacticoida (Crustacea, Copepoda) aus Slovenien. Acta Mus. Maced. Sci. Nat. 1983, 16, 177-205.

89. Chappuis, P.A. Nouveaux Copépodes cavernicoles. Bul. Soc. St. Cluj. 1928, 4, 20-34.

90. Klie, W. Zwei neue Arten der ostracoden-Gattung Candona aus unterirdischen Gewassern im sudostlichen Europa. Zool. Anzeige 1931, 96, 161-169.

91. Griffiths, H.I.; Brancelj, A. Preliminary list of freshwater Ostracoda (Crustacea) from Slovenia. Ann. Istrian Mediterr. Stud. 1996, 9 , 201-210.

92. Mori, N.; Meisch, C. Contribution to the knowledge on the distribution of recent free-living freshwater ostracods (Podocopida, Ostracoda, Crustacea) in Slovenia. Nat. Slov. 2012, 14, 5-22.

93. Birstein, J.A. Nahoždenie peščernoj krevetki v gruntovyh vodah Macesty i svjazannye s etim voprosy. Byull. Mosk. Obs. Isp. Prir. Otd. Biol. 1948, 53, 3-10.

94. Zakšek, V.; Sket, B.; Gottstein, S.; FranjeviĆ, D.; Trontelj, P. The limits of cryptic diversity in groundwater: Phylogeography of the cave shrimp Troglocaris anophthalmus (Crustacea: Decapoda: Atyidae). Mol. Ecol. 2009, 18, 931-946. [CrossRef] [PubMed]

95. Jugovic, J.; Jalžić, B.; Prevorčnik, S.; Sket, B. Cave shrimps Troglocaris s. str. (Dormitzer, 1853), taxonomic revision and description of new taxa after phylogenetic and morphometric studies. Zootaxa 2012, 3421, 1-31. [CrossRef]

96. Sket, B. Niphargus aquilex dobati ssp. n. (Crustacea) from the karst of Slovenia. Mitt. Verb. dt. Hoehlen- u. Karstforsch 1999, 45, 54-56.

97. Trontelj, P.; Blejec, A.; Fišer, C. Ecomorphological convergence of cave communities. Evolution 2012, 66, 3852-3865. [CrossRef] [PubMed]

98. Sket, B. Niphargobates orophobata n.g., n.sp. (Amphipoda, Gammaridae s.l.) from cave waters in Slovenia. Biološki Vestn. 1981, 29, 105-118.

99. Verovnik, R.; Prevorčnik, S.; Jugovic, J. Description of a neotype for Asellus aquaticus Linné, 1758 (Crustacea: Isopoda: Asellidae), with description of a new subterranean Asellus species from Europe. Zool. Anz. 2009, 248, 101-118. [CrossRef]

100. Verovnik, R.; Sket, B.; Trontelj, P. The colonization of Europe by the freshwater crustacean Asellus aquaticus (Crustacea: Isopoda) proceeded from ancient refugia and was directed by habitat connectivity. Mol. Ecol. 2005, 14, 4355-4369. [CrossRef]

101. Verovnik, R.; Sket, B.; Trontelj, P. Phylogeography of subterranean and surface populations of water lice Asellus aquaticus (Crustacea: Isopoda). Mol. Ecol. 2004, 13, 1519-1532. [CrossRef]

102. Prevorčnik, S.; Blejec, A.; Sket, B. Racial differentiation in Asellus aquaticus (L.) (Crustacea: Isopoda: Asellidae). Arch. Hydrobiol. 2004, 160, 193-214. [CrossRef]

103. Prevorčnik, S.; Jugovic, J.; Sket, B. Geography of morphological differentiation in Asellus aquaticus (Crustacea : Isopoda : Asellidae). J. Zool. Syst. Evol. Res. 2009, 47, 124-131. [CrossRef]

104. Racovitza, E.G. Notes sur les Isopodes. 13. Morphologie et phylogenie des Antennes II. Arch. Zool. Exp. Gén. 1925, 63, 533-622.

105. Sket, B. Taksonomska problematika vrste Asellus aquaticus (L.) Rac. (Crust., Isopoda) s posebnim ozirom na populacijo v Sloveniji. Slov. Akad. Znan. Umet. razred za Prirodosl. Med. vede. Razprave-Dissertationes 1965, 8, 3-45.

106. Prevorčnik, S.; Verovnik, R.; Zagmajster, M.; Sket, B. Biogeography and phylogenetic relations within the Dinaric subgenus Monolistra (Microlistra) (Crustacea: Isopoda: Sphaeromatidae), with a description of two new species. Zool. J. Linn. Soc. 2010, 159, 1-21. [CrossRef] 
107. Sket, B. Östliche gruppe der Monolistrini (Crust, Isopoda), I, Systematischer Teil. Int. J. Speleol. 1964, 1, 163-189. [CrossRef]

108. Strouhal, H. Asseln aus Balkanhohlen. Zool. Anz. 1938, 124, 269-281.

109. Strouhal, H. Titanethes Schiodte. Landasseln aus Balkanhohlen in der Kollektion "Biospeologica balcanica" von Prof. Dr. Absolon. 6. Mitteilung. Studien aus dem Geibete der Allg. Karstforschung, der wissenschaftlichen Hohlenkunde, der Eiszeitforsch. und den Nachbargebieten. Biologische Ser. 1939, 5, 5-34.

110. Strouhal, H. Landasseln aus Balkanhöhlen, gesammelt von Prof. Dr Karl Absolon. 10. Mitteilung.Zugleich 26. Beitrag zur Isopodenfauna des Balk. allg. Karstforsch., etc. Briinn 1939, 7, 1-37.

111. Potočnik, F.; Novak, T. Uber Landasseln (Isopoda terrestris) aus Hohlen Sloweniens. Anzeiger der math.-naturw. Klasse Osterr. Akad. Wissenschaften Jahrgang 1980 1980, 5, 75-81.

112. Stach, J. The species of the genus Arrhopalites Born. occurring in European caves. Acta Musei Hist. Nat. Acad. Pol. Litt. Sci. 1945, 1 , $1-47$.

113. Stach, J. Die Gattung Oncopodura Carl \& Leb und eine neue Art derselben aus den Höhlen nord-östl. Italiens. Bull. Acad. Pol. Sci. Sér. Sci. Biol. 1934, 2, 1-16.

114. Denis, J.R. Collemboles d'Italie (principalement cavernicoles) (sixieme note sur la faune italienne des Collemboles). Estratto Boll. Soc. Adriat. Sci. Nat. 1938, 26, 95-165.

115. Silvestri, F. Illustrazione della Plusiocampa (Stygiocampa) nivea Jospeh (Campodeidae, Diplura) delle grotte di Postumia. Boll. Lab. Entomol. Agrar. Portici 1947, 8, 88-92.

116. Daffner, H. Revision der Anophthalmus-Arten und-Rassen miz lang und dicht behaarter Korperoberseite (Coleoptera, Carabidae, Trechinae). Mitteilungen der Münchener Entomol. Gesellschaft 1996, 86, 33-78.

117. Daffner, H. Die Arten und Rassen der Anophthalmus schmidti und -mariae Gruppe (Coleoptera: Carabidae: Trechinae). Acta Entomol. Slov. 1998, 6, 99-128.

118. Bognolo, M. Il genere Bathyscimorphus (Coleoptera: Cholevidae). Coleoptera 2002, 6, 1-33.

119. Pretner, E. Catalogus Faunae Jugoslaviae III/6. Coleoptera, Catopidae, Bathysciinae; ZRC SAZU: Ljubljana, Slovenia, 1968.

120. Broder, J. Bythoxenus subterraneus Motshcoulsky 1859 (Coleoptera. Pselaphidae) ponovno najden v Sloveniji leta 1975. Naše Jame 1978, 19, 59-61.

121. Müller, G. I Pselafidi cavernicoli del Carso Adriatico settentrionale (Venezia Giulia e Carniola). Boll. Soc. Adriat. Sc. Nat. Trieste 1947, 43, 133-146.

122. Poggi, R. Forme nuove o poco note di Pselaphidae cavernicoli del Friuli-Venezia Giulia e della Jugoslavia. Mem. Soc. Ent. Ital. 1991, 70, 201-224.

123. Nonveiller, G.; Pavićević, D. Description d'une sous-espèce nouvelle et de six espèces nouvelles du genre Machaerites Miller, 1855 de Slovénie et de Croatie (Coleoptera, Pselaphinae, Bythinini). Nouv. Rev. Entomol. 2001, 18, 317-333.

124. Sket, B. Distribution of Proteus (Amphibia: Urodela: Proteidae) and its possible explanation. J. Biogeogr. 1997, 24, 263-280. [CrossRef]

125. Zagmajster, M.; Culver, D.C.; Christman, M.C.; Sket, B. Evaluating the sampling bias in pattern of subterranean species richness: Combining approaches. Biodivers. Conserv. 2010, 19, 3035-3048. [CrossRef]

126. Du Preez, G.; Majdi, N.; Swart, A.; Traunspurger, W.; Fourie, H. Nematodes in caves: A historical perspective on their occurrence, distribution and ecological relevance. Nematology 2017, 19, 1-18. [CrossRef]

127. Delić, T.; Trontelj, P.; Rendoš, M.; Fišer, C. The importance of naming cryptic species and the conservation of endemic subterranean amphipods. Sci. Rep. 2017, 7, 3391. [CrossRef] [PubMed]

128. Lukić, M.; Delić, T.; Pavlek, M.; Deharveng, L.; Zagmajster, M. Distribution pattern and radiation of the European subterranean genus Verhoeffiella (Collembola, Entomobryidae). Zool. Scr. 2019, 49, 86-100. [CrossRef]

129. Fišer, C.; Robinson, C.T.; Malard, F. Cryptic species as a window into the paradigm shift of the species concept. Mol. Ecol. 2018, 27, 613-635. [CrossRef] [PubMed]

130. Mammola, S.; Amorim, I.R.; Bichuette, M.E.; Borges, P.A.V.; Cheeptham, N.; Cooper, S.J.B.; Culver, D.C.; Deharveng, L.; Eme, D.; Ferreira, R.L.; et al. Fundamental research questions in subterranean biology. Biol. Rev. 2020, 95, 1855-1872. [CrossRef] [PubMed]

131. Protas, M.; Jeffery, W.R. Evolution and development in cave animals: From fish to crustaceans. Wiley Interdiscip. Rev. Dev. Biol. 2012, 1, 823-845. [CrossRef] [PubMed]

132. Jemec, A.; Škufca, D.; Prevorčnik, S.; Fišer, Ž.; Zidar, P. Comparative study of acetylcholinesterase and glutathione S-transferase activities of closely related cave and surface Asellus aquaticus (Isopoda: Crustacea). PLoS ONE 2017, 12, e0176746. [CrossRef] [PubMed]

133. Fišer, Ž.; Prevorčnik, S.; Lozej, N.; Trontelj, P. No need to hide in caves: Shelter-seeking behavior of surface and cave ecomorphs of Asellus aquaticus (Isopoda: Crustacea). Zoology 2019, 134, 58-65. [CrossRef]

134. Pipan, T.; Christman, M.C.; Culver, D.C. Abiotic community constraints in extreme environments: Epikarst copepods as a model system. Diversity 2020, 12, 269. [CrossRef]

135. Venarsky, M.P.; Huntsman, B.M.; Huryn, A.D.; Benstead, J.P.; Kuhajda, B.R. Quantitative food web analysis supports the energy-Limitation hypothesis in cave stream ecosystems. Oecologia 2014, 176, 859-869. [CrossRef]

136. Venarsky, M.P.; Benstead, J.P.; Huryn, A.D.; Huntsman, B.M.; Edmonds, J.W.; Findlay, R.H.; Wallace, J.B.; Bruce Wallace, J. Experimental detritus manipulations unite surface and cave stream ecosystems along a common energy gradient. Ecosystems 2018, 21, 629-642. [CrossRef] 
137. Mulec, J.; Oarga, A.; Šturm, S.; Tomazin, R.; Matos, T. Spacio-temporal distribution and tourist impact on airborne bacteria in a cave (Škocjan Caves, Slovenia). Diversity 2017, 9, 28. [CrossRef]

138. Mammola, S.; Cardoso, P.; Culver, D.C.; Deharveng, L.; Ferreira, R.L.; Fišer, C.; Galassi, D.M.P.; Griebler, C.; Halse, S.; Humphreys, W.F.; et al. Scientists' warning on the conservation of subterranean ecosystems. Bioscience 2019, 69, 641-650. [CrossRef]

139. Mulec, J.; Petrič, M.; Koželj, A.; Brun, C.; Batagelj, E.; Hladnik, A.; Holko, L. A multiparameter analysis of environmental gradients related to hydrological conditions in a binary karst system (underground course of the Pivka River, Slovenia). Acta Carsologica 2020, 48, 313-327. [CrossRef]

140. Šebela, S.; Turk, J. Local characteristics of Postojna cave climate, air temperature, and pressure monitoring. Theor. Appl. Climatol. 2011, 105, 371-386. [CrossRef]

141. European Council Directive 92/43/EEC of 21 May 1992 on the conservation of natural habitats and of wild fauna and flora; EU Council: Brussels, Belgium, 1992.

142. Tautz, D.; Arctander, P.; Minelli, A.; Thomas, R.H.; Vogler, A.P. A plea for DNA taxonomy. Trends Ecol. Evol. 2003, 18, 70-74. [CrossRef]

143. Leese, F.; Altermatt, F.; Bouchez, A.; Ekrem, T.; Hering, D.; Mergen, P.; Pawlowski, J.; Piggott, J.J.; Rimet, F.; Steinke, D.; et al. DNAqua-Net: Developing new genetic tools for bioassessment and monitoring of aquatic ecosystems in Europe. Res. Ideas Outcomes 2016, 2, e11321. [CrossRef]

144. Gorički, Š.; Stanković, D.; Snoj, A.; Kuntner, M.; Jeffery, W.R.; Trontelj, P.; Pavićević, M.; Grizelj, Z.; Năpăruş-Aljančič, M. Environmental DNA in subterranean biology: Range extension and taxonomic implications for Proteus. Nat. Publ. Gr. 2017, 91-93. [CrossRef]

145. Niemiller, M.L.; Porter, M.L.; Keany, J.; Gilbert, H.; Fong, D.W.; Culver, D.C.; Hobson, C.S.; Kendall, K.D.; Davis, M.A.; Taylor, S.J. Evaluation of eDNA for groundwater invertebrate detection and monitoring: A case study with endangered Stygobromus (Amphipoda: Crangonyctidae). Conserv. Genet. Resour. 2018, 10, 247-257. [CrossRef] 